\title{
Studi Tentang Perhatian Orang tua terhadap Pengembangan Konsep Diri Anak Usia 5-6 Tahun di TK Pelangi Kerasaan
}

\author{
Yuyun Ayunda ${ }^{(1)}$, Jasper Simanjuntak ${ }^{(2)}$, Anada Leo Virganta ${ }^{(3)}$ \\ ${ }^{(1)}$ Mahasiswa Program Studi PG PAUD FIP UNIMED \\ ${ }^{(2)}$ Dosen Program Studi PG PAUD FIP UNIMED \\ ${ }^{(3)}$ Dosen Program Studi PG PAUD FIP UNIMED \\ Jl. Williem Iskandar Pasar V Medan Estate, Medan, Sumatera Utara,20371\
}

Email: jaspersimanjuntak15@gmail.com

\begin{abstract}
Abstrak. Permasalahan dalam penelitian ini adalah perhatian orang tua dalam memberikan konsep diri anak yang masih belum optimal. Penelitian ini bertujuan untuk mengetahui bagaimana tingkat dan bentuk pemberian perhatian orang tua dalam mengembangkan konsep diri anak usia 5-6 tahun di TK Pelangi Kerasaan. Jenis penelitian ini menggunakan penelitian studi kasus. Teknik Analisis data dalam penelitian ini menggunakan kualitatif deksriptif. Populasi dalam penelitian ini satu kelas berjumlah 20 orang anak. Kemudian yang ber usia 5-6 tahun ada 6 orang anak. Maka peneliti mengambil sampel sebanyak 6 orang anak yang sesuai dengan usia 5-6 tahun. Penentuan sampel dilakukan secara sampling purposive yang dipilih sesuai dengan usia anak, Variabel dalam penelitian ini adalah perhatian orang tua dan konsep diri anak.

Berdasarkan hasil analisis data diketahui bahwa dalam pemberian perhatian orang tua kepada anaknya ada 3 sample yang telah memberikan perhatian penuh kepada anaknya, 2 sample masih kurang dalam memberikan perhatian dan 1 sampel telah memberikan perhatian yang cukup kepada anaknya. Bentuk perhatian yang sudah dilakukan oleh orang tua yaitu bimbingan belajar,memberikan reward dan motivasi pada setiap hasil capaian yang telah didapat anak, memberikan pengawasan dan memenuhi kebutuhan anak.
\end{abstract}

Kata Kunci: Konsep diri, Perhatian Orang Tua, Anak usia 5-6 tahun

\section{PENDAHULUAN}

Konsep diri seseorang tegambarkan dalam hal-hal yang berkaitan dengan individu. Pandangan terhadap diri, evaluasi diri, serta harapan terhadap diri sendiri dalam membentuk konsep diri individu. Sosok individu yang sedang menjelani suatu proses perkembangan yang sangat pesatdan fundamental untuk kehidupan selanjutnya terjadi pada anak usia 0-6 tahun. Pengembangan konsep diri hendaknya sudah dilakukan sejak dini.

Pendidikan anak usia dini sangat penting dilakukan sebab PAUD merupakan peletakan dasar bagi anak untuk mencapai ke-enam aspek seperti: NAM, bahasa, fisik motorik, kognitif, sosem dan seni. Menurut solehuddin (2000) anak usia dini adalah " sosok individu yang sedang mengalami proses perkembangan dengan sangat pesat dan sangat fundamental bagi kehidupan selanjutnya". Hal ini yang perlu dipersiapkan dengan cara membina dan mengembangkan segala pertumbuhan dan perkembangan anak khusunya orang tua dan guru. pendidikan seharusnya tidak hanya menekankan pada kemampuan 
intelegensi saja, namun pendidikan juga harus diberikan untuk pengembangan perilaku perlu diterapkan untuk menciptakan generasi penerus bangsa yang berkualitas.

Keluarga adalah unit social terkecil yang memberikan fondasi primer bagi perkembangan anak, juga memberikan pengaruh yang menentukan pembentukan watak dan kepribadian anak yaitu memberikan stempel yang tidak bisa dihapuskan bagi kepribadian anak. Baik buruknya keluarga memberikan dampak positif maupun negative bagi pertumbuhan anak menuju pendewasaannya. Lingkungan keluarga adalah lingkungan pertama tempat anak untuk belajar dalam bersosialisasi. Hal ini yang membuktikan bahwa lingkungan keluarga memilliki peranan penting dalam menumbuhkembangkan anak. Didalam keluarga anak harus didik menjadi anak yang mengenal konsep dirinya.

Menurut Nasution (2012:103) bahwa " orang tua adalah setiap orang yang bertanggung jawab dalam suatu keluarga atau rumah tangga, yang penghidupan sehari-hari dan lazim disebut "ibu dan bapak" berdasarkan pernyataan tersebut berarti orang itulah yang memiliki peran utama dalam setiap perkembangan anak. Perhatian yang diharapkan disini adalah perhatian yang penuh. Hal ini sesuai dengan pendapat Ahmad (2012:24) yang menyatakan bahwa " seorang anak memerlukan perhatian yang tidak terbagi-bagi dari kedua orang tuanya terutama mengenai luapan perasaan mereka tentang masalah yang dialami mereka". Maknanya yaitu orang tua harus dengan serius memperhatikan dan memahami anak dan tidak hanya mendongengkan cerita saja, dengan adanya perhatian penuh kepada anak sehingga anak merasa dihargai.

Orang tua merupakan pendidik utama yang sangat memberikan pengaruh banyak dalam setiap tahap perkembangan anak. Manusia lahir tidak memahami tentang siapa dirinya, dan bagaimana dia harus berprilaku semestinya. Oleh karna itu maka dalam mengembangkan konsep diri anak harus dilakukan oleh orang tua.

Konsep diri yang tinggi pada anak dapat tercipta apabila kondisi keluarga ditandai dengan adanya integritas dan tenggang rasa yang tinggi antar keluarga keluarga. Santrock (2010:75) mengemukakan adanya integritas dan tenggang rasa, serta sikap positif dari orang tua ,akan menyebabkan anak memandang orang tua sebagai figure yang berhasil dan mengangap ayah sebagai teman karib atau orang yang dapat dipercaya. Kondisi keluarga yang demikian dapat membuat anak menjadi lebih percaya dalam membentuk seluruh aspek dalam dirinya karna ia mempunyai model yang dapat dipercaya.

Namun pada kenyataan dilapangan, berdasarkan hasil observasi pada di TK Pelangi , konsep diri anak masih kurang terbentuk. Contohnya ada beberapa anak yang tidak percaya diri jika ditanya mengenai siapa namanya, tempat tinggalnya dimana, ciri-ciri fisiknya seperti apa, serta 
ada juga anak yang cenderung menutup diri, takut, malu dengan kemampuan yang dimilikinya.

Masalah yang peneliti kemukakan hampir sama dengan penelitian yang dilakukan Ahmad Fauzi (2012) yang menunjukkan bahwa " konsep diri yang ada pada diri anak masih kurang terbentuk. Hal ini dapat dilihat dari rasa percaya diri anak yang kurang, tidak mengetahui akan identitas dirinya, seperti namanya, ciri-ciri fisiknya dan hal yang berkenaan tentang diri Anak tersebut.

Mayoritas orang tua yang berada di TK Pelangi adalah orang tua yang bekerja karna kebanyakan waktu orang tua digunakan untuk bekerja, sehingga orang tua belum sepenuhnya memperhatikan tahap-tahap perkembangan anaknya, tetapi mereka tetap memberikan perhatian kepada anaknya. Namun ada juga orang tua yang hanya fokus dirumah untuk mengurus anaknya khususnya sang ibu, dan kaum ibu tersebut selalu mendampingi serta memberikan perhatian seperti mengawasi dan memberikan motivasi kepada anaknya saat anaknya sedang bermain dengan temannya maupun saat berada dirumahnya.

Pemberian perhatian orang tua dalam membentuk konsep diri anak dapat dilakukan dengan cara: komunikasi yang baik, melatih anak-anak untuk mengekspresikan dirinya, seperti berbicara tentang perilaku dari kedua perilaku yang berbeda, kemudian orangtua memberikan nasihat yang mendorong anak untuk menjadi lebih baik, serta menunjukkan penghargaan secara terbuka, hindari membuat anak menjadi kurang percaya diri.

Penanaman konsep diri anak usia 5 tahun menurut pendapat Brendt mengidentifikasi konsep diri melalui penampilan fisik(psycal appearnce), tindakan yang khas(typcal action), kepemilikan(possession) serta kemampuan(competence). Pola pengasuhan orang tua yang efektif dilakukan khususnya pada tingkat pemberian perhatian kepada anak agar pada anak usia dini konsep dirinya dapat berkembang . karna jika anak telah memahami akan dirinya anak akan menjadi percaya diri saat ada dilingkungan. Itulah sebabnya pemberian perhatian dari orang tua sangatlah penting. Peranan yang lebih besar diberikan orang tua agar kelak anak-anak mereka dapat menjadi anak yang membanggakan. Dari latar belakang yang telah dipaparkan maka penulis tertarik mengangakat judul "Studi Tentang Perhatian Orang Tua Terhadap Pengembangan Konsep Diri Anak Usia Dini ".

\section{KAJIAN TEORI}

Konsep diri sering disebut dengan istilah pandangan atau sikap individu terhadap dirinya. Konsep diri tersebut behubungan dengan sikap dan keyakinan tentang dirinya sendiri. 
Konsep diri menurut Hurlock (2007:89) merupakan" gambaran yang dimiliki seseorang tentang dirinya yang merupakan gabungan dari keyakinan tentang dirinya sendiri, karakter fisik, social, emocional, dan prestasi". Menurut yamin (2013:91) menjelaskan bahwa " konsep diri mencakup seluruh pandangan individu tentang dimensi fisik, karateristik pribadi, motivasi, kelemahannya, kepandaiannya, kegagalanya, dan sebagainya. Dari kedua defenisi diatas maka konsep diri merupakan sikap atau pandangan individu terhadap seluruh keadaan dirinya sendiri.

Erikson mengemukakan delapan tahap perkembangna individu bahwa anak usia 5-6 tahun itu termasuk termasuk kedalam tahap perkembangan tekun dan rendah diri. Pada tahap ini anak akan terfokus pada kemampuan, imajinasi, intelektual, dimana lingkungan sangat berpengaruh dalam membentuk konsep diri anak yang nantinya apakah positif atau negative. Hal ini sejalan dengan pendapat (Feeney 2006), Chirestense dan Moravick yang mengatakan bahwa konsep diri seseorang dipengaruhi oleh lingkungan jika lingkungan positif maka akan membentuk konsep diri yang positif. Penanaman konsep diri anak usia 5 tahun menurut pendapat Brendt mengidentifikasi konsep diri melalui penampilan fisik(psycal appearnce), tindakan yang khas(typcal action), kepemilikan(possession) serta kemampuan(competence).

Peranan konsep diri bagi individu dalam berprilaku tidak dapat diragukan lagi, sebab konsep diri merupakan pusat dari perilaku individu. Konsep diri adalah pemikiran seseorang tentang ciri khas dirinya yang meliputi ciri fisik, jenis kelamin, kecenderungan tingkah laku, watak ,emosional, dan cita-cita.

Ketika seorang anak merasa bahwa ia tidak dapat melakukan apa-apa maka itu menunjukkan adanya sisi negative terhadap kemampuan yang dimilikinya. Padahal seseorang akan bisa berhasil jika ia menggali selalu bakat yang dimilikinya.

Konsep diri tidak dibawa seseorang sejak dia lahir, tetapi konsep diri dapat terbentuk saat ada penanaman dari orang tua maupun pengalaman yang didapatkan anak melalui hubungan dengan orang lain. Dalam berinteraksi maka anak akan menerima tanggapan. Tanggapan yang diterima oleh anak akan menjadi cerminan pada dirinyauntuk menilai dan memandang dirinya.jadi konsep diri terbentuk pada saat anak melakukan proses umpan balik.

Anak pertama kali akan mengenal keluarganya dan berinteraksi pertama kali dari orang tua dan anggota keluarganya, maka dapat di pastikan anak menerima tanggapan pertama kali adalah dari lingkungan keluarga.

Maka Konsep diri memiliki peranan dalam tindakan dan sikap seseorang, oleh karna itu penerapan dan penanaman konsep diri perlu 
dilakukan sejak dini . penanaman konsep diri adalah penanaman cara berfikir kepada anak.

\section{METODE PENELITIAN}

Jenis penelitian berupa penelitian dengan metode atau pendekatan studi. Penelitian ini memusatkan pada objek tertentu yang mempelajarinya sebagai suatu kasus. Analisis data dalam penelitian ini adalah kualitatif deksriftif. Wolf dan Tymiz dalam buku sukardi $(2006 ; 2)$ menyatakan bahwa: penelitian kualitatif bertujuan untuk mengetahuiatualitas, realitas social dan persepsi manusia melalui pengakuan mereks, yang mungkin tidak dapat diungkap melalui penonjolan pengkuran formal atau pertanyaan penelitian yang telah dipersiapkan terlebih dahulu, kemudian peneliti akan mendeksripsikan atau menggambarkan semua secara lengkap, rinci dan mendalam. Oleh karna itu jenis penelitian ini dianggap tepat.

\section{Subjek Penelitian}

Jumlah keseluruhan anak usia 5-6 tahun di TK Pelangi kerasaan ada 20 orang anak, tetapi anak usia 5-6 tahun hanya ada 6 orang anak. Maka peneliti mengambil subjek penelitian sebanyak 6 orang usia 5-6 di TK Pelangi Kerasaan Secara sederhana oleh Miles and Huberman (dalam Sugiyono 2013: 337) mengemukakan bahwa aktivitas dalam menganalisis data kualitatif dilakukan secara interaktif dan berlangsung secara terus menerus sampai tuntas sehingga datanya sudah jenuh.

Aktivitas dalam analisis data yaitu data reduction, data display dan conclusion verification. Dalam penelitian menggunakan model analisis interaktif. Pada dasarnya model analisis interaktif prosesn berbentuk siklus yang artinya pada bentuk ini peneliti tetap bergerak diantara tiga kompenan analisis dengan proses pengumpulan data selama kegiatan pengumpulan berlangsung. Sesudah pengumpulan data berakhir, maka peneliti bergerak diantara tiga komponen analisanya dengan menggunakan waktu yang ada . Adapun gambaran dari uraian tersebut adalah seperti berikut:

1. Pengumpulan Data

Dalam penelitian ini pengumpulan data dilakukan dengan observasi dan wawancara secara sistematik. Peneliti mewawancarai sebanyak 6 Orangtua mengenai bentuk-bentuk pemberian perhatian kepada anaknya. Kemudian peneliti juga melihat (observasi) mengenai konsep diri anak di TK Pelangi.

2. Reduksi Data 
Dalam penelitian ini yang menjadi reduksi data adalah berbagai hal yang berhubungan dengan perhatian orang tua dalam mengembangkan konsep diri pada anak. Dan yang menjadi abstraksi data dalam penelitian ini adalah pemberian perhatian orang tua untuk membentuk konsep diri anak.

3. Penyajian Data

Berdasarkan data yang terkumpul dan setelah dianalisis, selanjutnya dapat dikategorikan bahwa dalam pemberian perhatian yang dilakukan oleh orang tua kepada anak masuk kedalam kategori Rendah, Cukup, atau Baik.

4. Penarikan kesimpulan

Penarikan kesimpulan dalam penelitian ini adalah data hasil observasi dan wawancara yang dilakukan peneliti kepada 6 orang tua dan 6 Orang anak dalam pemberian perhatian terhadap pembentukan konsep diri anak tersebut.

\section{Validitas Data}

Cara pengumpulan data dengan beragam tekniknya harus benar benar sesuai dan tepat untuk menggali data yang benar benar diperlukan di dalam penelitian. Ketepatan data tersebut tidak hanya tergantung pada ketepatan memilh sumber data dan teknik pengumpulannya, tetapi juga diperlukan teknik pengembangan validitas datanya. Untuk memperoleh tingat keabsahan data, teknik yang digunakan antara lainnya 1) Meningkatkan ketekunan ,melakukan pengamatan secara lebih cermat dan berkesinambungan. Dengan meningkatkan ketekunan maka peneliti dapat melakukan pengecekan kembali apakah data yang telah ditemukan itu salah atau tidak. Demikin juga dengan meningkatkan ketekunan maka peneliti dapat memberikan deksripsi data yang akurat dan sistematis tentang apa yang diamati. 2)Triangulasi teknik dilakukan dengan cara mengecek data kepada sumber yang sama dengan teknik yang berbeda. Data yang diperoleh dengan wawancara lalu dicek dengan observasi, dokumentasi

\section{HASIL PENELITIAN DAN PEMBAHASAN}

Berdasarkan rumusan masalah pada penelitian ini yaitu bagaimana tingkat pemberian perhatian orang tua dalam mengembangkan konsep diri anak dan bentuk perhatian seperti apa yang telah dilakukan oleh orang tua dalam mengembangkan konsep diri anak tersebut, maka yang pertama saya akan menjabarkan tingkat perhatian orang tua dari hasil observasi dan wawancara yang sudah saya lakukan

Hasil observasi dan wawancara terhadap Responden A menunjukkan bahwa orang tua telah memberikan perhatian secara penuh kepada anak, 
hal tersebut dapat dilihat dari segi konsep diri anaknya juga menunjukkan konsep diri yang baik. Orang tua ikut memberikan dukungan penuh hobi yang dilakukan oleh anaknya dan memberikan reward dari setiap pencapaian yang telah didapat oleh anaknya, kedekatan orang tua dengan anaknya juga sangat dekat, dan orang tua responden A selalu mengawasi setiap apa saja yang dilakukan oleh anaknya.

Hasil dari wawancara dan observasi pada Responden B menunjukkan bahwa orang tua masih kurang memberikan perhatian kepada anaknya, seperti pada bagian komunikasi dengan anak dan pemberian dukungan serta pengawasan kepada anak masih kurang hal tersebut juga menunjukkan hasil konsep diri anak juga menunjukkan kurang baik.

Wawancara dan observasi pada Responden C telah memberikan perhatian dengan penuh, hal tersebut juga dapat dilihat dari hasil observasi menunjukkan bahwa orang tua mendukung hobi anaknya, mememberika fasilitas belajar untuk anaknya dan membimbing anaknya menjadi anak yang mandiri seperti anak memakai baju sendri dan memakai sepatu sendiri.

Wawancara dan observasi pada Responden D telah memberikan perhatian kepada anak tergolong cukup hal ini dapat dilihat seperti pada bagian dukungan dalam mengembangkan hobi anak dan pengawasan kepada anak, orang tua tidak memantaunya dikarnakan bekerja diluar kota. hal itu juga terlihat pada hasil observasi konsep diri anak tergolong cukup.

Hasil dari wawancara dan observasi pada Responden $\mathbf{E}$ telah memberikan perhatian penuh kepada anaknya hal tersebut juga tampak pada saat berada dirumah, orang tua memiliki kedekatan dengan anaknya dan selalu mendukung dan mengawasi setiap kegiatan yang dilakukan oleh anaknya, kemandirian juga ditanamkan oleh orang tuanya tidak hanya itu orang tua juga memberikan reward dari setiap hasil yang telah dicapai anaknya.

Wawancara dan observasi pada Responden $\mathbf{F}$ orang tua kurang dalam memberikan perhatian pada anaknya sepetiri bagian komunikasi, dukungan, waktu bersama anak dan pengawasan kepada anak masih kurang hal tersebut juga sama dengan hasil konsep diri anak masih tergolong rendah. 
Pendapat Feeney dalam Chirestense dan Moravick (2006; 23-25) yang mengatakan bahwa konsep diri seseorang dipengaruhi oleh lingkungan, jika lingkungan positif maka akan membentuk konsep diri yang positif. Dengan adanya pemberian perhatian pada anak maka pengembangan konsep diri anak juga akan berkembang seiring berjalannya waktu, bisa membentuk konsep diri yang positif namun bisa juga sebaliknya menjadi konsep diri yang negative, tergantung pada tingkat perhatian orang tua kepada anaknya. hasil temuan peneliti mengenai perhatian orang tua dengan konsep diri anak dapat disimpulkan sebagai berikut:

Maka kesimpulan dari hasil temuan tersebut adalah pemberian perhatian dari orang tua sangat berpengaruh pada pembentukan konsep diri anak. Karna anak memerlukan kedekatan dengan orang tua seperti memberikan dukungan, motivasi, penghargaan, dan pengawasaan dari setiap kegiatan yang dilakukan anak

\section{SIMPULAN}

Berdasarkan penjelasan data dari temuan peneliti, maka dapat disimpulkan bahwa penerapan perhatian orang tua dalam mengembangkan konsep diri anak usia 5-6 tahun di TK Pelangi Kerasaan

1. Terdapat 3(tiga) orang anak yang memiliki konsep diri yang tinggi, 1(satu) orang anak memiliki konsep diri yang cukup dan 2(dua) orang memiliki konsep diri yang kurang.

2. Dari ke-enam sample penelitian ternyata tingkat perhatian orang tua menunjukkan bahwa 3(tiga) sampel telah memberikan perhatian secara penuh kepada anaknya , 2(dua) sampel menunjukkan perhatian yang masih kurang kepada anaknya dan 1(satu) sampel menunjukkan perhatian yang cukup kepada anaknya.

3. Bentuk perhatian yang sudah dilakukan oleh orang tua tersebut yaitu sudah melakukan interaksi dengan anak, kemudian memberikan fasilitas belajar kepada anak, memberikan suatu reward terhadap setiap hasil yang sudah didapat anaknya serta dukungan dan motivasi kepada anak.

\section{DAFTAR PUSTAKA}

Azwar. 2012 tentang panduan kategorisasi https://www.kajianpustaka.com/2015/12/panduan kategorisasi.html

Dudaro, Angelita, D, Dkk. 2013.hubungan dukungan orang tua dengan konsep diri pada remaja di SMA negeri 1 Manado

Gunarsa, S.D. 2013. Psikologi untuk keluarga, Jakarta : Bumi Aksara 
Hosnan, N. 2016. Psikologi perkembangan peserta didik. Bogor; Ghalia Indonesia

Purwanto, ngalim, 2004. Psikologi pendidikan bandung : Remaja Rosdakarya

Riadi Muchsin. 2015 tentang perhatian orang tua. https://www.kajianpustaka.com/2015/12/perhatian-orangtua.html

Senirman, C, 2009. Penerapan pembelajaran pada anak. Jakarta : indeks.

Supandi 2011, menyiapkan kesuksesan anak anda.jakarta: gramedia pustaka utama.

Syarif K.2015, Perkembangan peserta didik. Jakarta indeks.

Sugiyono, 2014. Metode penelitian pendidikan bandung. Alfabeta cv

Sudjana Ibrahim,1994.penelitian dan penilaian pendidikan. Bandung

Sumadi Suryabrata, 2007. Psikologi pendidikan. Jakarta: Raja Grafindo Persada.

Sutopo, 2002. Metode Penelitian Kualitatif , Jakarta Remaja Rosdakarya

Yamin M dan Sabri J. 2013.Panduan pedoman PAUD. Gaung persada press group. 